\title{
PERAN INTERMEDIASI PERBANKAN TERHADAP USAHA MIKRO KECIL DAN MENENGAH (UMKM)
}

\author{
Oleh \\ Nurul Badriyah \\ Fakultas Ekonomi Universitas Brawijaya Malang \\ E-mail/No.Hp: - / 0816554892
}

\begin{abstract}
Bank is a business entity which accummulate funds from society in a form of saving and distributing it to society in a form of credit or other forms available in order to enhance the standard of living of society in general. Bank play role as intermediary institution which bridging two party with different self interest, whether in accumulating or investing, or even in providing other banking services including clearing. SMEs is one of business entity characterized as self liquidating since all of their funding acquired from financial institution is used to finance their business activity. It is different with corporate, where usually funding that is acquired from bank is mostly used for investment or complimenting the fixed capital of company. SMEs is not least important as bigger scale business entity, including in credit distribution since SMEs is proven to have significant and important role in economic development.
\end{abstract}

Keywords: Intermediary role, Banking, Small \& Medium Enterprises

\section{PENDAHULUAN}

Dalam proses intermediasi (di sektor keuangan) terdapat hubungan antara Ultimate Lender (UL), yaitu pemilik dana di masyarakat, dengan Ultimate Borrower (UB), yaitu pengguna dana untuk menjalankan aktivitas ekonomi. Ultimate Lender adalah kelompok "penabung". Jumlah seluruh tabungan kelompok ini membentuk penawaran loanable funds. Sementara ultimate borrower adalah kelompok masyarakat yang memerlukan dana untuk operasi atau perluasan usahanya. Jenis kelompok yang terakhir ini didominasi oleh golongan pengusaha, perusahaan, atau industri. Lembaga keuangan, termasuk dengan bank, berada di antara ultimate lender dan ultimate borrower untuk menjembatani hubungan khas antara keduanya, memberikan jasa intermediasi berupa proses keperantaraan antara surplus unit dengan deficit unit dalam ekonomi.
Jadi, tidak berlebihan jika dikatakan bank memiliki tempat yang teramat penting dalam perekonomian. Karena peran bank sebagai lembaga yang dapat memengaruhi kegiatan perekonomian melalui perannya di dalam proses penciptaan kredit serta berbagai jasa keuangan lain yang diberikan.

Berdasarkan Undang-undang Nomor 7 Tahun 1992 sebagaimana telah diubah dengan Undang-undang Nomor 10 Tahun 1998 tentang Bank Umum maupun ketentuan prinsip bank sebagai lembaga intermediasi jelas tertulis bahwa "Bank merupakan lembaga intermediasi antara nasabah penyimpan dana pihak ketiga (giro, tabungan, deposito) untuk disalurkan ke dunia bisnis dalam upaya meningkatkan taraf hidup orang banyak."

Jadi, bank adalah badan usaha yang menghimpun dana dari masyarakat dalam bentuk simpanan dan 
menyalurkannya kepada masyarakat dalam bentuk kredit dan/atau bentukbentuk lainnya dalam rangka meningkatkan taraf hidup rakyat banyak. Peningkatan taraf hidup rakyat terjadi karena adanya kesempatan kerja dari investasi dunia bisnis, yang bersumber dari dana kredit perbankan. Pasca Undang-undang Nomor 7 Tahun 1992, hanya dikenal dua jenis bank, yaitu bank umum dan bank perkreditan rakyat (BPR). Menurut regulasi tersebut, perbedaan bank umum dengan BPR adalah terletak dalam kegiatannya, yaitu BPR tidak memberikan jasa dalam lalu lintas pembayaran sedangkan bank umum diizinkan memberikan jasa dalam lalu lintas pembayaran (UU No. 7/1992).

Tanpa membedakan jenisnya dan berdasarkan pemaknaan bank di atas, bank berperan sebagai lembaga intermediasi yang mempertemukan dua pihak yang berbeda kepentingannya, baik dalam penghimpunan dan penanaman dana, maupun dalam jasa layanan perbankan lainnya termasuk jasa layanan lalu lintas pembayaran (khusus bank umum). Peran tersebut mencerminkan aktivitas-aktivitas utama dari bank. Pertama, menghimpun dana dari masyarakat. Kedua, menanamkan dana yang dikelolanya ke dalam berbagai aset produktif, misalnya kredit. Ketiga, memberikan jasa layanan lalu lintas pembayaran (khusus bank umum) dan jasa layanan perbankan lainnya. Semua aktivitas tersebut adalah kegiatan keseharian internal bank yang bermuara kepada tujuan utamanya yaitu mencari keuntungan.

Dalam penyajian neraca sebuah bank, secara umum terdapat sisi aktiva dan sisi pasiva. Di sisi pasiva terdapat beberapa akun antara lain: Giro, Deposito, Kewajiban, Surat berharga, dan akun Lain-lain. Sementara di sisi aktiva terdapat beragam jenis akun, mulai dari Kas, Tagihan Pada Bank
Lain, Surat Berharga Bank, Penyertaan, sampai akun Kredit yang Disalurkan.

Salah satu jenis kredit yang disalurkan oleh bank adalah kredit khusus perbankan yang ditujukan pada sektor usaha. Pada dasarnya penyaluran kredit ini adalah kegiatan pokok bank. Artinya, hakikat kegiatan pasiva bank adalah penggunaan dana atau manajemen aset, yaitu menyalurkan kredit. Terdapat kegiatan manajemen aset/aktiva lainnya, tetapi tentu saja bukan merupakan kegiatan pengelolaan dana yang utama dan porsinya juga teramat kecil.

Kredit tersebut berfungsi sebagai pemenuhan untuk melayani kebutuhan masyarakat (to serve the society) dalam rangka mendorong dan melancarkan perdagangan, mendorong dan melancarkan produksi, jasa-jasa dan bahkan konsumsi yang kesemuanya itu pada akhirnya ditujukan untuk menaikkan taraf hidup rakyat banyak. Manfaat kredit tidak hanya bagi debitur, tapi juga bagi kreditur, dalam hal ini bank. Beberapa manfaat itu antara lain perolehan pendapatan berupa bunga dan potensi membaiknya rentabilitas bank akibat perolehan laba yang meningkat, kesempatan bank memasarkan produk/jasa bank lainnya, sampai pada terbukanya kesempatan bagi bank untuk mendidik dan meningkatkan kemampuan para personilnya untuk lebih mengenal secara rinci kegiatan usaha secara riil di berbagai sektor ekonomi.

Dalam menjalankan fungsi penyaluran dana dengan memberikan pelayanan kredit, bank bisa memilih untuk menyalurkan kreditnya kepada sektor usaha yang dipandangnya mampu mendatangkan profit yang layak menurut penilaiannya, baik itu kepada corporate maupun sektor usaha dengan skala yang kecil. Pada gilirannya, hal ini menghasilkan konsekuensi tentang jaminan atau agunan terhadap 
pembiayaan yang dilakukan oleh bank. Jika demikian, maka sudah sewajarnya jika bank memutuskan untuk memprioritaskan pemberian kredit kepada sektor usaha yang mampu memberikan jaminan terhadap pembiayaan tersebut.

Usaha berskala besar, dengan demikian, akan mendapatkan prioritas utama dalam penyaluran kredit. Sementara usaha kecil, harus rela menjadi prioritas kesekian, yang itu pun masih dengan syarat ketersediaan jaminan yang cukup.

Dalam bahasan tentang kredit perbankan inilah dirasakan penting untuk menelaah tentang pembiayaan kepada sektor Usaha Mikro Kecil Dan Menengah (UMKM). Karena, secara sejarah dan prinsip filosofi bank, semua jenis pembiayaan (pada sektor usaha yang besar maupun kecil), bisa dilakukan oleh bank, selama usaha tersebut bersifat self liquidating. Berdasarkan teori perbankan yang mendasar (awal), yaitu teori pemberian pinjaman untuk dagang, the commercial loan theory, bank-bank hanya boleh memberikan pinjaman dengan surat dagang jangka pendek yang dapat dicairkan dengan sendirinya (selfliquidating), karena sifat sesungguhnya dari pinjaman itu ialah menghasilkan uang yang diperlukan untuk membayarnya kembali.

UMKM adalah salah satu jenis usaha yang sifatnya self liquidating, karena pada umumnya seluruh dana pembiayaan yang diperoleh dari lembaga keuangan digunakan untuk pembiayaan kegiatan usaha. Berbeda dengan usaha corporate, dimana biasanya pembiayaan yang didapatkan dari perbankan sebagian besar digunakan untuk pembiayaan investasi, atau melengkapi perusahaan dengan modal yang tetap.

Semua pihak tampaknya sepakat bahwa sektor usaha berskala kecil
(UMKM) harus diperhatikan sama pentingnya dengan sektor usaha berskala besar, tentunya termasuk dalam hal penyaluran kredit. Adalah sangat tidak adil jika penyaluran kredit untuk memacu roda pembangunan hanya difokuskan pada usaha berskala besar saja. Sektor kecil, dalam hal ini UMKM, bagaimanapun memiliki andil yang signifikan dan tidak kalah pentingnya dalam pembangunan dan perekonomian nasional.

Pertumbuhan UMKM sendiri mulai menjadi topik yang cukup hangat sejak munculnya tesis flexible specialization pada tahun 1980-an, yang didasari oleh pengalaman dari sentrasentra Industri Skala Kecil (ISK) dan Industri Skala Menengah (ISM) di beberapa negara di Eropa Barat, khususnya Italia. Sebagai contoh kasus, pada tahun 1970-80an, pada saat Industri Skala Besar di Inggris, Jerman, dan Italia mengalami stagnasi atau kelesuan, ternyata Industri Skala Kecil yang membuat produk-produk tradisional mengalami pertumbuhan yang pesat dan bahkan mengembangkan pasar ekspor untuk barang-barang tersebut dan menyerap banyak tenaga kerja.

Fenomena di Asia, sebagai perbandingan, bisa dilihat dari pengalaman Taiwan, China, Thailand, Vietnam, Hongkong dan Indonesia sendiri (Gambar 1). 


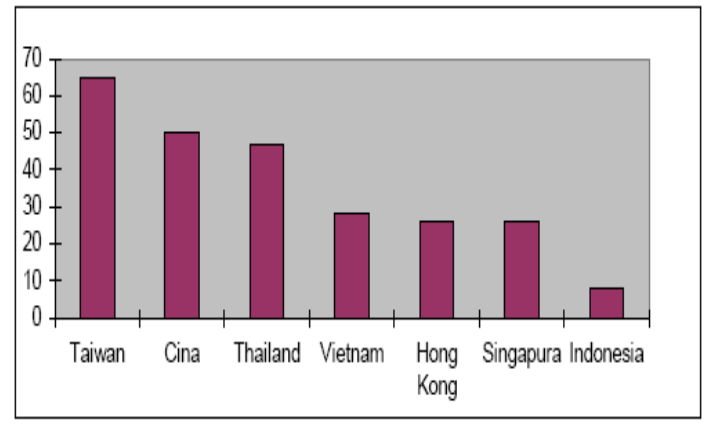

Gambar 1. Peranan UMKM dalam Ekspor di Beberapa Negara Asia, $1996 \quad$ (dalam persentase)

Sumber: Tambunan, 1999; dalam Kuncoro, 2003

Setidaknya, sampai pertengahan tahun 1990an, Taiwan menjadi leader di antara beberapa negara Asia dalam perkembagan UKM yang menopang sebagian besar ekspornya. Pengalaman Taiwan menunjukkan perekonomiannya dapat tumbuh pesat karena ditopang oleh sejumlah usaha kecil dan menengah yang disebut community-based industry. Perkembangan industri di Taiwan yang sukses menembus pasar global ternyata ditopang oleh kontribusi UMKM yang dinamik.

Di Indonesia, UMKM mempunyai peranan yang cukup penting terutama bila ditilik dari segi jumlah unit usaha dan tenaga kerja yang diserapnya. Peranan UMKM dalam perekonomian Indonesia pada dasarnya sudah besar sejak dulu dan meningkat dengan tajam sejak krisis ekonomi melanda Indonesia. Data dari Biro Pusat Statistik (BPS) menunjukkan bahwa persentase jumlah UMKM dibandingkan total perusahaan pada tahun 2001 adalah sebesar 99,9\%. Pada tahun yang sama, jumlah tenaga kerja yang terserap oleh sektor ini mencapai $99,4 \%$ dari total tenaga kerja. Pada periode berikutnya angka tersebut meningkat menjadi $99,5 \%$ pada tahun 2003 dan tahun 2004. Demikian juga sumbangannya pada Produk Domestik
Bruto (PDB) juga besar, lebih dari separuh ekonomi kita didukung oleh produksi dari UMKM $(59,3 \%$ pada tahun 2001, 58,3\% pada tahun 2003 dan $58,6 \%$ pada tahun 2004). Sedangkan data dari Kementrian Koperasi dan UKM menunjukkan bahwa sampai tahun 2005 saja, kontribusi UMKM begitu besar bila dibandingkan dengan usaha besar (Tabel 1).

Data-data tersebut menunjukkan bahwa peranan UMKM dalam perekonomian Indonesia adalah sentral dalam menyediakan lapangan pekerjaan dan menghasilkan output dan UKM mempunyai peran sebagai salah satu penggerak kegiatan ekonomi di Indonesia.

UMKM memegang peranan yang penting dalam perkembangan perekonomian di Indonesia, karena: pertama, kontribusi yang signifikan berkaitan dengan penyerapan tenaga kerja. Kedua, pemerintah Indonesia menempatkan prioritas lebih tinggi untuk UMKM. Ketiga, potensi kontribusi UMKM dalam mengembangkan usaha yang dilaksanakan oleh pribumi. Keempat, pentingnya formulasi kebijakan perekonomian yang sesuai dengan karakteristik UMKM. Kelima, harapan atas kontribusi UMKM untuk meletakkan dasar bagi pertumbuhan industri. Keenam, UMKM telah terbukti lebih tahan terhadap deraan dan tempaan krisis ekonomi yang dialami Indonesia tahun 1997-1998.

Selain perannya yang signifikan terhadap perekonomian nasional, terutama dalam peningkatan jumlah unit usaha dan tenaga kerja yang diserapnya sehingga bisa menjadi katup pengaman dalam usaha pencapaian pertumbuhan ekonomi Indonesia, UMKM juga mempunyai daya survive tersendiri dalam menghadapi kejutan dalam perekonomian. 
Pasca krisis ekonomi 1997, sementara sektor korporat masih dalam proses restrukturisasi yang berjalan lamban, sektor UMKM telah menunjukkan perkembangan yang terus mengalami peningkatan. Selain itu, karakteristik usaha UMKM dapat memberikan hasil (return) yang relatif lebih cepat dibandingkan dengan usaha korporasi.

Periode krisis yang berkepanjangan, telah membawa dampak terhadap sendi-sendi kehidupan ekonomi masyarakat Indonesia. Namun dalam kondisi yang demikian, ternyata justru usaha kecillah yang mampu menjadi katup pengaman perekonomian dengan kinerja yang cenderung relatif resisten terhadap goncangan ekonomi. terbukti selama krisis (1998-2001), UMKM lebih tangguh menghadapi krisis ekonomi (Tabel 2).

Meskipun telah banyak bukti tentang besarnya peran UMKM dalam perekonomian Indonesia, banyak studi yang mengemukakan tentang kendala yang dihadapi UMKM untuk berkembang, terutama dari sisi permodalan. UMKM terutama di Indonesia memiliki 4 permasalahan utama yang dapat menghambat perkembangannya. Keempat permasalahan tersebut adalah: kurangnya pengetahuan tentang teknologi produksi dan pengendalian mutu, kurangnya kemampuan pemasaran, kurangnya pengetahuan manajemen dan kurangnya akses ke pendanaan secara formal.

Berdasarkan data BPS tahun 2002,

Tabel 1. Kontribusi UMKM Vs Usaha Besar -2005

\begin{tabular}{|c|c|c|c|c|c|}
\hline & $\begin{array}{l}\text { Kecil } \\
\text { (Termasuk } \\
\text { Milkro) }\end{array}$ & $\begin{array}{l}\text { Menen } \\
\text { gah }\end{array}$ & $\begin{array}{l}\text { Total } \\
\text { UMKKM }\end{array}$ & Besar & Total \\
\hline Jumlah Unit & $44,621,823$ & 67,78 & $44,689,608$ & 4.171 & $44,693,77$ \\
\hline$(0 \%) \quad$ Porsi & 99.84 & 0.15 & 9999 & 0.01 & 100 \\
\hline $\begin{array}{l}\text { Jml Tenaga } \\
\text { Kerja (orang) }\end{array}$ & $71,187,153$ & $\begin{array}{l}6491,3 \\
45\end{array}$ & $77,678,498$ & $2,590,275$ & $\begin{array}{l}80,268,77 \\
3\end{array}$ \\
\hline Porsi $(0,6)$ & 88.69 & 809 & 9677 & 3.23 & 100 \\
\hline $\begin{array}{l}\text { Jumlah PDB } \\
\text { (Rp } \\
\text { juta) }\end{array}$ & $1,039,576,900$ & $\begin{array}{l}437,61 \\
7,400\end{array}$ & $\begin{array}{l}1,477,194,3 \\
00\end{array}$ & $950,397,500$ & $\begin{array}{l}2,427,591 \\
800\end{array}$ \\
\hline Porsi $(0,0)$ & 42.82 & 18.03 & 60.85 & 39.15 & 100 \\
\hline $\begin{array}{l}\text { Jumlah } \\
\text { Ekspor }\end{array}$ & $27,699,835$ & $\begin{array}{l}81,429 . \\
060\end{array}$ & $\begin{array}{l}109,128,89 \\
5\end{array}$ & $460,459,569$ & $\begin{array}{l}569,588,4 \\
64\end{array}$ \\
\hline Porsi $(0,0)$ & 4.86 & 143 & 19.16 & 8084 & 100 \\
\hline
\end{tabular}

Sumber: Kementerian Koperasi dan UKM, 2005

Tabel 2. Dampak Krisis Ekonomi Medio 1997 Terhadap UMKM (Dalam \%)

\begin{tabular}{lcc}
\hline \multicolumn{1}{c}{ Dampak } & Indonesia & Jawa Timur \\
\hline Tidak Terpengaruh & 16,82 & 23,00 \\
Terpengaruh tapi dapat diatasi & 38,56 & 38,40 \\
Terpengaruh tapi belum teratasi & 12,39 & 11,69 \\
Justru mengalami peningkatan & 1,02 & 1,23 \\
Tidak tahu & 8,63 & 9,82 \\
Berdiri setelah Juni 1997 & 22,57 & 19,45 \\
To t a l & 100,00 & 100,00
\end{tabular}

Sumber : BPS, Profil UMKM Tidak Berbadan Hukum Selain Sektor Pertanian - 2002 
Berdasar pada permasalahan kurangnya akses ke pendanaan secara formal (salah satunya ke lembaga perbankan), survei yang dilakukan di Jawa Timur oleh JBIC-DAI-REDI tentang akses kredit dan pertumbuhan usaha kecil pada tahun 2004, menunjukkan bahwa 45\% UMKM menilai masih perlu dana kredit perbankan, namun 50\% dari UMKM yang butuh kredit tersebut tidak mau ke Bank Umum dengan alasan 1) Adanya persepsi prosedur bank yang rumit; 2) Waktu Keputusan Kredit lama dan 3) Persyaratan cukup berat.

Sementara berdasarkan hasil penelitian Biro Kredit Bank Indonesia (2006:1) menggambarkan angka yang lebih besar, yaitu sebagian besar UMKM $(64,6 \%)$ memerlukan kredit. Namun demikian, sumber pembiayaan usaha mikro dan kecil sebagian besar masih berasal dari modal pribadi dan modal keluarga. Sejalan dengan hal tersebut, survei BPS (1998) menyatakan bahwa keterbatasan akses modal sebagai kendala utama bagi usaha mikro $(40,5 \%)$ dan kecil $(36,6 \%)$ untuk berkembang. Meskipun banyak sumber dana yang tersedia, tetapi sumber tersebut belum banyak dimanfaatkan karena belum ada titik temu UMKM sebagai debitur dan pihak bank sebagai kreditur.

Dari sisi UMKM, beberapa kendala dalam mengakses permodalan dari bank adalah suku bunga yang tinggi dan kesulitan memenuhi persyaratan agunan. Selain itu kredit perbankan juga sulit untuk diakses oleh UMKM, di antaranya karena prosedur yang rumit serta banyaknya UMKM yang belum bankable. Apalagi BI tidak lagi membantu usaha kecil dalam bidang permodalan secara lansung dengan diberlakukannya UU No.23 Tahun 1999 tentang Bank Indonesia. Sedangkan dari sisi perbankan, permasalahan UMKM terletak pada kelayakan usaha, baik aspek keuangan maupun aspek pemasaran dan tenaga kerja.

Selain permasalahan yang sudah disebutkan sebelumnya, secara umum UMKM menghadapi dua permasalahan utama, yaitu masalah finansial dan masalah nonfinansial (organisasi manajemen). Adapun masalah yang termasuk dalam masalah finansial di antaranya adalah: 1) kurangnya kesesuaian (terjadinya mismatch) antara dana yang tersedia yang dapat diakses oleh UMKM; 2) tidak adanya pendekatan yang sistematis dalam pendanaan UMKM; 3) Biaya transaksi yang tinggi, yang disebabkan oleh prosedur kredit yang cukup rumit sehingga menyita banyak waktu sementara jumlah kredit yang dikucurkan kecil; 4) kurangnya akses ke sumber dana yang formal, baik disebabkan oleh ketiadaan bank di pelosok maupun tidak tersedianya informasi yang memadai; (5) bunga kredit untuk investasi maupun modal kerja yang cukup tinggi; (6) banyak UMKM yang belum bankable, baik disebabkan belum adanya manajemen keuangan yang transparan maupun kurangnya kemampuan manajerial dan finansial.

Menyimak kecenderungan berbagai kelemahan UMKM dari sisi finansial, sejatinya peran bank dalam pembiayaan kepada usaha berskala kecil, utamanya UMKM bukanlah tidak ada. Banyak bank yang meyakini bahwa pembiayaan kepada UMKM adalah hal prospektif bagi bank, karena melihat pertumbuhan ekonomi dan kondisi ekonomi makro selama tahun-tahun terakhir yang masih dimotori oleh sektor konsumsi dan industri kecil, yang disebabkan peran sektor industri dan investasi besar belum signifikan.

Tidak sedikit data yang menunjukkan tentang peningkatan kinerja kredit kepada UMKM. Pada 
salah satu laporan BI misalnya, dinyatakan bahwa sampai dengan bulan Desember 2006 saja, total kredit perbankan telah mencapai angka sebesar Rp. 792,2 triliun. Dari jumlah tersebut, porsi kredit untuk UMKM mencapai $51,60 \%$, sedangkan sisanya sebesar $48,20 \%$ untuk kredit korporasi. Bahkan jika dilihat dari tingkat pertumbuhannya, sejak tahun 2003 kredit untuk UMKM telah jauh melebihi tingkat pertumbuhan total kredit perbankan.

Kondisi pasar kredit yang sempat mengalami penurunan di masa krisis, kini telah normal kembali dengan penawaran kredit bank yang mampu memenuhi permintaan kredit dari debitur. Lebih dari itu, konvergensi kesenjangan penawaran dan permintaan kredit, rendahnya LDR, dan tingginya undisbursed loans menunjukkan bahwa permintaan kreditlah yang seharusnya perlu didorong untuk meningkatkan kredit perbankan, bukan dari sisi penawaran kredit. Dengan demikian, proses intermediasi perbankan juga telah banyak mengalami perbaikan. Peningkatan dana masyarakat, perbaikan kondisi internal perbankan, dan mulai bergairahnya kegiatan ekonomi telah mampu meningkatkan penyaluran kredit oleh perbankan.

Dalam tahun-tahun terakhir outstanding kredit perbankan meningkat rata-rata sekitar $17,5 \%$ per tahun, sehingga pada pertengahan 2004 saja mencapai Rp. 505,2 triliun. Dari jumlah tersebut besarnya kredit yang disalurkan kepada sektor UMKM mencapai Rp 210,9 triliun pada akhir tahun 2003 dan meningkat menjadi Rp 262,6 triliun pada
September 2004, dengan tingkat pertumbuhan tahunan sebesar $29,5 \%$.

Dengan demikian, sekitar separuh dari total kredit perbankan telah disalurkan kepada sektor UMKM, yaitu mencapai $48 \%$ dan $52 \%$ pada masingmasing tahun tersebut. Hal lain yang juga patut dicatat adalah semakin sehatnya struktur penyaluran kredit perbankan ke sektor UMKM tersebut, khususnya apabila dilihat dari besarnya plafon kredit yang diberikan.

Untuk posisi kredit UMKM pada akhir 2004, sebesar 46,3\% dalam bentuk kredit mikro dengan plafon sampai dengan Rp 50 juta, sementara kredit kecil (plafon dari Rp 50 juta s.d. Rp 500 juta) dan kredit menengah (plafon $\mathrm{Rp}$ 500 juta s.d. Rp 5 miliar) masing-masing mencapai $25,2 \%$ dan 28,6\%. Senada dengan hal tersebut, berikut disajikan rangkaian angka yang kurang lebih sama (Tabel 3.).

Namun demikian, dari banyak data, terdapat kondisi yang perlu juga dicatat dan perlu mendapatkan perhatian tentang kredit UMKM ini. Bahkan di tengah kondisi penawaran berlebih pada pasar kredit di Indonesia sekalipun, perkembangan sektor UMKM justru terhambat karena masalah kekurangan permodalan. Lebih lanjut mereka mengungkapkan bahwa hasil penelitian kerjasama Kementrian KUKM dan BPS pada tahun 2003 menunjukkan bukti bahwa untuk mengatasi kesulitan permodalannya, hanya sebanyak $17,50 \%$ dari UMKM tersebut yang melakukan pinjaman ke bank, sedangkan sisanya sebanyak $82,50 \%$ ke lembaga non bank atau informal. 
Tabel 3. Kredit Untuk UMKM Menurut Jenis Penggunaannya (Dalam Rp. Miliar)

\begin{tabular}{|c|c|c|c|c|}
\hline Kredit UMKM & 2002 & 2003 & 2004 & 2005 \\
\hline Investasi & 17,356 & 22,760 & 28,460 & 33,049 \\
\hline Modal Kerja & 73,679 & 91,129 & 111,636 & 142,633 \\
\hline Konsumsi & 69,942 & 93,199 & 130,997 & 179,225 \\
\hline Total kredit UMKM & 160,977 & 207,088 & 271,093 & 354,907 \\
\hline Persentase kredit UMKM dari total kredit perbankan & $43,38 \%$ & $47,01 \%$ & $48,46 \%$ & $51,02 \%$ \\
\hline
\end{tabular}

Sumber: Riskayanto dan Sulistiowati, 2006

Data dari Kementerian Koperasi dan UKM pada tahun 2005, juga memberikan informasi yang tak kalah penting tentang perkreditan UMKM ini. Berdasarkan data tersebut, diketahui jumlah UMKM di Indonesia mencapai lebih dari 44 juta unit usaha, sementara jumlah usaha besar hanya 4.171 unit usaha. Dari seluruh UMKM tersebut, diindikasikan baru sekitar $12 \%$ saja atau sebesar lima jutaan UMKM yang telah memperoleh kredit bank. Berarti, masih terdapat sekitar 39 juta UMKM yang belum terlayani oleh perbankan.

Kecilnya porsi kredit perbankan yang terserap oleh UMKM tersebut, layak dipandang sebagai suatu permasalahan dan sekaligus momentum tersendiri bagi upaya pengembangan UMKM dari aspek peningkatan peran intermediasi bank terhadap UMKM. Hal ini sejalan dengan upaya peningkatan peran dan kontribusi UMKM dalam perekonomian nasional. Salah satu upaya yang dapat dilakukan untuk maksud tersebut adalah menetapkan pemerataan hasil pembangunan yang mencakup program pemberian kesempatan kepada UMKM untuk memperluas dan mengatur usahanya, antara lain dengan jalan memperkuat permodalannya.

Dari berbagai permasalahan dan kondisi riil di lapangan tersebut dapatlah disimpulkan tentang perlunya upaya peningkatan peran intermediasi bank, khususnya peran intermediasi bank dalam pembiayaan kepada UMKM. Semua pihak tampaknya sepakat pada upaya peningkatan kredit UMKM ini, namun ironisnya yang justru sering terjadi adalah adanya ketidakseimbangan dalam hal pelayanan kredit. Kalangan pengusaha besar atau usaha berskala besar justru sering menikmati kemudahan-kemudahan. Apa saja kalau bisa ditawar, baik prosedur maupun persyaratannya, termasuk juga pemenuhan jaminannya. Kelompok usaha ini misalnya, sering agak diperlakukan "istimewa". Jaminan yang hanya berupa persediaan tidak jarang justru menjadi jaminan utama dalam kredit. Sementara kemudahankemudahan dan kelonggaran tersebut tampaknya tidak berlaku untuk pelaku usaha berskala kecil.

Berkaitan dengan permasalahan kurangnya penyaluran kredit, telah terjadi disintermediasi perbankan di Indonesia khususnya pasca Krisis 1997. Kredit yang disalurkan perbankan belum cukup menjadi mesin pendorong pertumbuhan ekonomi untuk kembali pada level sebelum krisis, yang berarti bahwa fungsi intermediasi perbankan masih belum pulih atau terjadi disintermediasi perbankan. Pandangan ini sejalan dengan kondisi dimana masih banyaknya dana kredit yang belum terserap oleh sektor usaha.

Karena sektor usaha yang jumlah unitnya besar adalah UMKM dan dari jumlah yang besar itu baru 12\% saja yang memanfaatkan kredit bank (berarti $88 \%$ yang belum memanfaatkan), maka wajar jika banyak kalangan menilai jika sektor ini bisa memanfaatkan besarnya dana kredit di bank, maka secara tidak 
langsung proses intermediasi perbankan bisa ditingkatkan.

Belum pulihnya fungsi intermediasi perbankan antara lain disebabkan oleh masih berlangsungnya konsolidasi internal perbankan dan belum mampunya sektor riil menyerap kredit. Belum selesainya proses restrukturisasi kredit telah menimbulkan potensi meningkatnya Non Performing Loans (NPLs). Sementara itu, konsolidasi internal perbankan seperti penerapan good corporate governance dan pengelolaan risiko yang baik masih merupakan proses yang dilaksanakan oleh perbankan. Semua hal tersebut sangat dicermati oleh perbankan karena pengaruhnya pada kecukupan modal perbankan atau CAR (Capital Adequacy Ratio).

Jika kondisinya demikian, maka dapatlah dimengerti jika kalangan perbankan masih enggan untuk menyalurkan kredit kepada sektor usaha yang kecil. Biaya dana yang mahal pasaca krisis, akan direspon bank dengan tindakan selektif dalam melakukan pembiayaan investasi, mengingat umumnya usaha kecil salah satunya bercirikan tidak mempunyai jaminan kredit yang cukup.

Berdasarkan praktik di lapangan, terdapat beberapa alasan yang menunjukkan tentang ketidakadilan bank dalm memberikan kredit utamanya terhadap usaha kecil. Berbagai alasan tersebut antara lain: Pertama, bank cenderung melakukan deferensiasi produk yang berorientasi kepada usaha untuk mengatasi persaingannya dengan lembaga pembiayaan lain, khususnya pasar modal. Takut akan kehilangan pangsa pasarnya, bank selalu melakukan deferensiasi produk agar fungsi substitusi itu berbalik kepada bank. Celakanya, karena pasar modal banyak berorientasi kepada perusahaan, maka deferensiasi produk perbankan juga menjadi marketable hanya bagi pengusaha besar.

Produk pembiayaan perbankan, seperti L/C, usance L/C, trust recep financing, forfaiting financing, dan factoring financing, pada akhirnya hanya marketable bagi kalangan pengusaha besar. Karena itu, wajar jika pembiayaan berskala besar tetap dapat diberikan oleh bank, tanpa harus mengacu kepada fixed asset collateral. Di lain pihak, untuk pengusaha kecil berlaku kaidah sebaliknya.

Kedua, adanya kecenderungan menggunakan acuan efisiensi berdasarkan pendekatan administrasi. Memberikan kredit puluhan juta, sama proses dan administrasinya dengan kredit ratusan milyar. Fenomena ini memberikan kesan lebih efisien dan efektif, kalau memberikan kredit dalam jumlah besar.

Ketiga, meskipun harus dibuktikan kebenarannya, terdapat kecenderungan kalangan perbankan telah menerima apa yang disebut dengan depolitical banking. Pengelolaan bisnis perbankan tidak lagi kalis terhadap tatanan pengelolaan bisnis perdagangan, industri, dan jenis usaha lainnya. 'Kemurnian' perbankan, seringkali menjadi banyak mengalami penyesuaian yang menjauhi azas keadilan. Gejalanya adalah kecenderungan pemberian kredit hanya kepada grupnya, kepada koleganya saja, sampai kepada pertimbangan prestise.

Sampai tahun 2005, kredit investasi yang dikucurkan untuk sektor UMKM baru mengambil porsi yang sangat kecil, yaitu hanya $9,31 \%$. Selain itu, karena kinerja kredit perbankan selama tahun 2005 menunjukkan bahwa kredit modal kerja dan investasi mencatat kredit bermasalah (NPL - Non Performing Loan) yang sangat tinggi, yaitu masing-masing sebesar 52,33\% dan $38,92 \%$ dari total NPL perbankan, sementara kredit konsumsi mencatat 
NPL yang jauh lebih rendah, yaitu sebesar $8,75 \%$ sehingga cukup beralasan apabila dunia perbankan akhirnya lebih gencar mengucurkan kredit konsumsi. Hal inilah antara lain yang menyebabkan iklim pemberian kredit investasi bisa dikatakan belum kondusif.

Permasalahan

tentang

disintermediasi perbankan khususnya pada UMKM pada dasarnya sangat terkait dengan profil dari debitur-debitur UMKM yang kebanyakan kurang atau bahkan tidak bankable (tidak memenuhi persyaratan persyaratan teknis perbankan). Tidak bankable-nya debitur UMKM menjadikan aspek kelayakan (feasibility) debitur UMKM terabaikan. Karena tidak dapat memenuhi persyaratan-persyaratan teknis perbankan, calon debitur UMKM jadi kehilangan kesempatan untuk mendapatkan fasilitas kredit dari perbankan.

Selain pandangan tidak bankablenya UMKM, sebab disintermediasi bank yang dilatari oleh karakteristik UMKM sendiri menyatakan bahwa tipologi UMKM secara umum kecil dan bersifat menyebar, menyebabkan cost atau biaya per unitnya menjadi mahal. Selain itu, tidak bisa dipungkiri bahwa agunan mereka umumnya terbatas, dan dalam beberapa kasus, malah tidak mempunyai agunan. Sehingga bagi perbankan, tentu saja ini akan menyebabkan risiko terhadap kreditnya menjadi tinggi. Selanjutnya, bagi bank, akan jauh lebih menguntungkan jika dana yang tersedia tidak disalurkan kepada usaha yang mengandung risiko tinggi. Karena bagaimanapun bank adalah lembaga bisnis.

Sebagaimana diketahui, dalam
setiap kegiatan usahanya, bank
mempunyai berbagai aktivitas yang
merupakan kegiatan keseharian yang
bermuara kepada tujuan utamanya yaitu
mencari keuntungan.

Namun jika dicermati, sebenarnya terdapat sisi lain dari karakteristik UMKM itu sendiri. Sifatnya yang kecil dan menyebar bisa dipandang sebagai keuntungan tersendiri dari segi risk yang dihadapi oleh bank. Sesuai dengan pepatah jangan letakkan telur dalam satu keranjang yang sama, kalau sejumlah besar dana disalurkan hanya kepada sektor usaha yang besar saja, yang jumlahnya relatif sedikit dibanding usaha kecil, maka jika terjadi kerugian terhadap usaha besar tersebut, tentu bank juga akan mengalami kerugian yang besar (bahkan dalam banyak kasus bisa mengalami kebangkrutan). Namun jika sejumlah dana tersebut disalurkan kepada usaha yang sifatnya menyebar, jika seandainya terjadi kerugian terhadap salah usaha tersebut, bank akan terhindar dari kerugian yang besar, karena usaha kecil yang lainnya masih bisa berjalan.

Tak sedikit UMKM yang cukup layak mendapat dukungan permodalan karena sangat potensial untuk dikembangkan. Namun, seringkali karena perbankan menerapkan peraturan dan prinsip kehati-hatian (prudential) pada manajemen risiko, kadangkala peluang bisnis (dengan melakukan pembiayaan pada UMKM) ini tidak termanfaatkan. Padahal kemurnian bisnis perbankan seharusnya mengacu kepada prinsip how to minimize the risk and how to distribute the risk.

Atas dasar prinsip tersebut, harusnya memberikan kredit yang hanya puluhan juta (kredit kecil), potential risknya lebih baik, karena akan tersebar kepada puluhan bahkan ratusan nasabah. Selain itu, tentu saja karena alasan yang mendasar bahwa sifat UMKM adalah self liquidating. Namun ternyata keadaan di lapangan menunjukkan hal sebaliknya.

Sejalan dengan wacana tentang terjadinya disintermediasi dan 
pentingnya peningkatan peran intermediasi perbankan, khususnya bagi pengembangan UMKM, menarik untuk menganalisis pengembangan UMKM dari sisi pembiayaannya melalui pendekatan klaster atau sentra industri. Sebagaimana diketahui, bahwa saat ini salah satu kebijakan yang tepat bagi pengembangan industri kecil dan upaya yang giat dilakukan dalam rangka terus memberdayakan UMKM adalah pengembangan UMKM melalui pendekatan klaster atau pembinaan sentra industri. Hal ini didasari alasan agar segala bentuk pembinaan maupun bantuan teknis terserap secara sempurna (dalam satu wadah). Selain itu juga karena alasan, pengalaman yang menunjukkan bahwa industri kecil di sentra-sentra dapat berkembang lebih pesat, lebih fleksibel dalam menghadapi perubahan pasar, dan dapat meningkatkan produksinya daripada industri kecil secara individu di luar sentra.

\section{FILOSOFI INTERMEDIASI PERBANKAN}

Lembaga perantara keuangan (lembaga intermediasi) adalah badan usaha yang kekayaannya terutama berbentuk likuid dan kewajibankewajibannya terutama dari simpanan masyarakat serta instrumen-instrumen utang yang diterbitkannya. Fungsi pokok lembaga ini adalah bertindak sebagai perantara antara unit surplus dengan unit defisit. Sedangkan menurut bentuk dan jenisnya, lembaga ini dapat digolongkan dalam berbagai badan usaha, seperti bank, perusahaan asuransi, perusahaan reksa dana, program dana pensiun atau perusahaan pembiayaan (misalnya, sewa guna, modal ventura, anjak piutang).

Lembaga keuangan sendiri merupakan bagian dari sistem keuangan, dimana sistem keuangan sendiri merupakan suatu jaringan pasar keuangan (financial market), yang ikut mendorong sistem keuangan, yang terdiri dari: institusi pasar uang dan pasar modal, sektor usaha, rumah tangga dan lembaga pemerintah yang merupakan peserta sekaligus memiliki wewenang mengatur operasi sistem keuangan tersebut. Fungsi utama sistem keuangan ini adalah mentransfer danadana dari unit surplus (ultimate lenders) kepada unit defisit (ultimate borrowers).

Dana yang dihimpun oleh lembaga perantara keuangan, selanjutnya dialokasikan atau ditempatkan di pasar uang yang akan mempertemukan kepentingan kepentingan pihak pensuplai dana dengan yang membutuhkan dana, dan dalam sistem perekonomian modern, dana yang mengalir melalui sistem keuangan yang dihimpun oleh bank, berasal dari unit rumah tangga, sementara peminjam dana dalam jumlah besar adalah unit-unit usaha. Selengkapnya hal ini dapat dilihat pada gambar 2 .

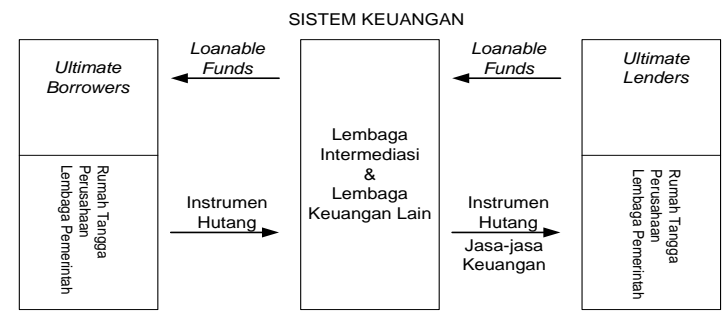

Gambar 2. Lembaga Keuangan dalam (Sumber: Siamat,1995) Sistem Keuangan

Dalam gambar 2. tersebut, dapat disimpulkan bahwa bank (bersama-sama dengan lembaga keuangan yang lain) berada di posisi penghubung sebagai lembaga yang menghubungkan surplus unit dan deficit unit. Lembaga intermediasi terutama bank, menjalankan perannya sebagai lembaga transfer dana dari surplus unit ke defisit unit dana.

Walaupun beberapa transfer dana finansial dari unit surplus ke definisi unit terbentuk secara langsung melalui 
peminjaman atau persamaan kontrak, perbedaan maksud/keinginan dari unit surplus dan defisit akan menciptakan kebutuhan intermediasi. Perbedaan maksud tersebut bisa berupa ukuran (besaran), batasan waktu pinjaman, karakter legal, kemampuan pasar, likuiditas, divisi, kemampuan menebus (redeemability), dan risiko. Misalnya, banyak dari surplus unit mempunyai dana yang secara relatif sedikit dan ingin dapat menukarkannya menjadi tunai dengan mudah dan dengan jangka waktu yang pendek.

Di sisi lain, unit defisit kebanyakan menginginkan sejumlah besar dana dengan jangka waktu/periode yang lama, dengan jaminan bahwa mereka akan diwajibkan membayar dengan pembayaran yang sudah diatur waktunya (jatuh tempo). Institusi yang berusaha menyatukan perbedaan keinginan dari unit surplus dan unit defisit tersebut disebut institusi intermediasi keuangan (financial intermediary).

Seiring dengan aktivitas ekonomi yang semakin berkembang, peranan bank sangat penting dalam mempengaruhi kinerja perekonomian, khususnya di Indonesia di mana perbankan menguasai sebagian besar pangsa dari sistim keuangan yang ada. Fungsi utama bank pada dasarnya memanglah sebagai lembaga intermediasi keuangan yang bertugas mengumpulkan dana dari masyarakat yang kelebihan dana (idle fund/surplus unit) kemudian menyalurkannya kepada masyarakat yang membutuhkan dana (deficit unit).

\section{PERAN INTERMEDIASI PERBANKAN BAGI SEKTOR USAHA DI INDONESIA}

Semua kalangan telah menyadari pentingnya pemantapan stabilitas pada aras makro sebagai prasyarat dasar untuk tercapainya peningkatan kesejahteraan rakyat melalui pertumbuhan yang tinggi dan peningkatan kualitas pertumbuhan tersebut. Untuk tujuan tersebut, harus terdapat keseimbangan antara sektor riil dan sektor keuangan sebagai penggerak utama sektor riil.

Lembaga keuangan, sebagai lembaga yang mendominasi sektor finansial dalam aktivitas perekonomian, diisyaratkan mampu menyumbangkan peran yang lebih besar dalam dalam proses penciptaan pertumbuhan tersebut melalui fungsi utamanya, yakni intermediasi.

Dalam suatu sistem perekonomian, peran utama lembaga-lembaga keuangan memang menjalankan fungsi intermediasinya. Yakni, menyalurkan kembali dana yang telah dihimpunnya dari masyarakat dalam bentuk pinjaman atau kredit kepada sektor usaha riil dalam upaya pengembangan usahanya. Dengan kata lain, melalui fungsi intermediasi yang dijalankannya, sektor keuangan haruslah berperan sebagai agen dalam mempercepat pembangunan dan meningkatkan pertumbuhan ekonomi, yang pada akhirnya akan meningkatkan kesejahteraan masyarakat.

Di Indonesia, lembaga keuangan yang paling berperan dalam proses pembangunan tersebut dari waktu ke waktu ialah perbankan. Jika fungsi intermediasi keuangan yang dimotori bank ini dapat berjalan dengan baik, maka kredit bank menjadi sangat esensial untuk mendorong pertumbuhan sektor riil. Sehingga tidaklah berlebihan jika dikatakan bahwa sektor usaha di Indonesia sangat bergantung pada perbankan, dalam arti pembiayaannya. Karena itu, dapatlah dimengerti jika ledakan krisis sektor perbankan pada tahun 1998 membawa dampak yang begitu terasa bagi perekonomian Indonesia.

Pembahasan mengenai peningkatan peran intermediasi 
perbankan terhadap sektor usaha di Indonesia, memang tidak bisa dipsahkan dari pembahasan tentang krisis ekonomi di Indonesia pada kisaran 1997-1998. Seperti diketahui bersama, bahwa krisis ekonomi yang terjadi di Indonesia dan berdampak sangat luas tersebut, diawali dengan krisis di bidang moneter.

Krisis ekonomi dan perbankan inilah yang kemudian mengakibatkan terjadinya distorsi pada intermediasi perbankan. Melonjaknya nilai tukar Rupiah terhadap Dollar Amerika, kebijakan suku bunga tinggi, dan kebijakan kredit perbankan, jauh sebelum krisis terakumulasi sehingga menciptakan permasalahan tersendiri bagi perbankan. Negative spreads, kerugian akibat selisih valas dan melonjaknya Non Performing Loan $(N P L)$ kemudian menjelma menjadi "pola umum" yang dihadapi perbankan. Pada gilirannya, hal ini berdampak terhadap kemampuan bank dalam menyalurkan kredit.

Selanjutnya pada periode-periode berikutnya setelah terjadinya krisis ekonomi, di satu sisi kondisi masih terbatasnya fungsi intermediasi perbankan dan belum kondusifnya iklim berinvestasi menjadi faktor fundamental yang menghambat pertumbuhan investasi yang lebih tinggi. Namun di sisi lain, krisis nilai tukar yang melahirkan krisis perbankan pada tahun 1997-1998 tersebut menjadi pengalaman traumatis baik di pihak perbankan sendiri, sektor riil, maupun regulator, terlebih masyarakat. Sehingga kemudian, konsep "prudent banking" dalam kerangka pengelolaan resiko menjadi hal yang paling diutamakan dalam pengoperasian bank pasca krisis moneter. Lahirnya konsep ini cenderung terasosiasi dengan fungsi intermediasi perbankan.
Meskipun di tahun-tahun terakhir upaya peningkatan kinerja perbankan secara umum dapat dikatakan mulai menunjukkan hasil, yang tercermin dari membaiknya beberapa kinerja perbankan, pendapat umum para ahli dan ekonom masih belum bisa menilai bahwa sektor yang terkena dampak krisis paling besar ini telah pulih. Artinya, agenda penyehatan perbankan masih belum optimal dalam memulihkan peran intermediasi perbankan. Padahal, sektor perbankan memainkan peranan yang sangat krusial dalam perekonomian.

Agenda penyehatan perbankan sendiri yang salah satunya dirumuskan melalui proses konsolidasi internal perbankan (antara lain berupa pemenuhan ketentuan $C A R$ dan $N P L$ ), selama ini telah membatasi kegiatan produksi dan investasi di sektor riil. Sementara di sektor keuangan, upaya tersebut telah menyebabkan tidak tersalurkannya kelebihan likuiditas dalam bentuk penyaluran kredit perbankan.

Tabel 4 menunjukkan gambaran tentang perkembangan dan kondisi perbankan Indonesia dari tahun ke tahun, pasca puncak krisis ekonomi 1999-2000. Berdasarkan data pada tabel tersebut dapat disimpulkan tentang permasalahan intermediasi perbankan di Indonesia, dimana perbankan nasional masih belum sepenuhnya berhasil dalam menjalankan fungsinya. Hal ini setidaknya dapat dilihat melalui perkembangan Loan to Deposit Ratio (LDR) dan Capital Adequacy Ratio (CAR).

Pada perkembangan terakhir saja (tahun 2006), angka LDR kurang lebih hanya sebesar 60\%. Rasio ini masih terkategorikan sebagai angka yang rendah, mengingat aktivitas utama dari bank adalah penyaluran kredit. 
Tabel 4. Perkembangan Indikator Perbankan Indonesia

\begin{tabular}{lrrrrrr}
\hline \multicolumn{1}{c}{ Indiktor } & 2001 & 2002 & 2003 & 2004 & 2005 & 2006 \\
\hline $\begin{array}{l}\text { Dana Pihak Ketiga } \\
\text { Rp.Triliun) }\end{array}$ & 797.36 & 835.78 & 888.57 & 963.11 & $1,127.9$ & $1,287.0$ \\
$\begin{array}{l}\text { Kredit (Rp. Triliun) } \\
\text { Loan to Deposit }\end{array}$ & 316.06 & 371.06 & 440.51 & 559.47 & 730.2 & 832.9 \\
$\begin{array}{l}\text { Ratio (LDR) [\%] } \\
\text { Return On Assets }\end{array}$ & 33.01 & 38.24 & 43.52 & 49.95 & 64.7 & 64.7 \\
$\begin{array}{l}\text { ROA) [\%] } \\
\text { Non Performing }\end{array}$ & 1.45 & 1.96 & 2.63 & 3.46 & 2.6 & 2.6 \\
$\begin{array}{l}\text { Loan (NPL) [\%] } \\
\text { Capital Adequacy }\end{array}$ & 12.23 & 7.5 & 6.78 & 4.5 & 8.3 & 7.0 \\
Ratio (CAR) [\%] & 19.93 & 22.44 & 19.43 & 19.42 & 19.5 & 20.5 \\
\hline $\begin{array}{l}\text { Sumber:Purwanto (2005:2);Thalo (2005:6); dan Statistik Perbankan, Bank Indonesia } \\
\text { (2006:52) }\end{array}$
\end{tabular}

Di satu sisi rendahnya $L D R$ menunjukkan belum optimalnya peran intermediasi yang dijalankan perbankan (disintermediasi). Di sisi lain, tingkat $L D R$ yang rendah juga menunjukkan masih cukup besarnya ruang bagi ekspansi kredit. Rendahnya LDR tentunya berkonsekuensi pada tingginya likuiditas yang dihadapi perbankan. Likuiditas yang berlebih ini kemudian ditanam di SBI dan meninggalkan sektor riil pada kondisi yang kembang kempis.

Tingginya akselerasi pertumbuhan dana masyarakat di bank (DPK/Dana Pihak Ketiga) yang tidak dibarengi oleh pertumbuhan kredit seperti yang terjadi pada perbankan di Indonesia ternyata menyebabkan perbankan mengalami penguatan likuiditas, yang terindikasi dari semakin banyaknya dana bank yang disimpan dalam Sertifikat Bank Indonesia (SBI).

Hal tersebut mengisyaratkan ketidakmampuan bank-bank untuk menyalurkan dana yang dihimpunnya ke dalam bentuk kredit dan atau aktiva produktif lainnya, sehingga tidak memilki alternatif penyaluran dana lain di luar SBI.

Hal lain yang perlu disadari pula, bahwa penempatan dana yang besar pada SBI tidak hanya memperkecil penyaluran kredit ke sektor riil, tapi juga akan membawa dampak tersendiri bagi bank, dimana konsekuensi dari penempatan dana bank dalam jumlah yang besar pada SBI akan menghilangkan potensi bank untuk memperoleh keuntungan yang lebih tinggi.

Sementara itu, tingkat $C A R$ yang jauh di atas ketentuan Bank Indonesia (8\%) juga menunjukkan hal yang sama. Atau dari sisi yang lain tingginya $C A R$ ini juga menunjukkan bahwa perbankan mengalami over liquid. Kondisi over liquid inilah yang menjadi salah satu penyebab tingginya biaya dana yang pada gilirannya berdampak pada tingginya tingkat bunga kredit.

Dari beberapa indikator di atas dapat disimpulkan bahwa perbankan masih belum optimal dalam menjalankan peran intermediasinya. Dalam kondisi yang demikian pemulihan dunia usaha sulit untuk diharapkan.

\section{PERMASALAHAN BANK DAN PERMASALAHAN SEKTOR USAHA DI INDONESIA}

Pembahasan mengenai peran intermediasi perbankan di Indonesia juga bisa dijelaskan melalui identifikasi permasalahan yang dihadapi oleh 
perbankan (sebagai kreditur), maupun oleh sektor usaha usaha sendiri (sebagai debitur).

Dalam kaitan dengan permasalahan yang dihadapi oleh kelompok bank, bank lebih banyak bersikap hati-hati karena latar belakang pengalaman krisis, sehingga bank lebih memilih menempatkan dananya pada SBI dan obligasi pemerintah yang dapat dikatakan memberikan tingkat pengembalian yang cukup tinggi dengan risiko nol dan juga biaya administratif yang rendah. Jadi, bisa disimpulkan bahwa secara umum, perbankan Indonesia cenderung menghindari risiko (risk-aversion) ketimbang mengelolanya (risk-management).

Selanjutnya, belum pulihnya fungsi intermediasi perbankan seperti tercermin dari terputusnya keterkaitan sektor riil dan keuangan akibat riskaversion bukan hanya menyebabkan terbatasnya pembiayaan kegiatan investasi dan modal kerja bagi proses pemulihan ekonomi, namun juga adanya kelebihan likuiditas di perbankan yang berpotensi memberi tekanan pada nilai tukar rupiah dan inflasi.

Bukti lain yang menunjukkan bahwa bank lebih suka menghindari risiko adalah pertumbuhan kredit yang sebagian besar masih didominasi oleh kredit konsumsi. Hal ini tidak mengherankan karena kredit konsumsi dengan nominal per transaksi lebih kecil jika dibandingkan kredit lainnya. Dengan kata lain, kredit konsumsi relatif lebih kecil risikonya dibandingkan kredit lainnya.

Dalam kaitan dengan tingginya kredit konsumsi dan rendahnya investasi, kebijakan pemerintah untuk mengakselerasikan pembangunan infrastruktur sebagai prasyarat pendukung pertumbuhan ekonomi sebesar 6\% tampaknya belum dapat membangkitkan semangat bank besar untuk menyambutnya dengan antusias. Penyebabnya adalah karena kinerja kredit perbankan (selama tahun 2005 misalnya) menunjukkan bahwa kredit modal kerja dan investasi mencatat kredit bermasalah (NPL - Non Performing Loan) yang sangat tinggi, yaitu masing-masing sebesar 52,33\% dan 38,92\% dari total NPL perbankan. Sementara itu, kredit konsumsi mencatat NPL yang jauh lebih rendah, yaitu sebesar $8,75 \%$ sehingga cukup beralasan apabila dunia perbankan akhirnya lebih gencar mengucurkan kredit konsumsi.

Namun hal yang harus disadari, pertumbuhan ekonomi dengan bertopang pada konsumsi tidak akan sustainaible dalam jangka panjang. Kontribusi investasi pada pertumbuhan ekonomi akan menciptakan multiplier yang memadai untuk menciptakan pertumbuhan ekonomi yang sustainaible. Untuk itu diperlukan dukungan kredit investasi dan modal kerja yang memadai.

Langkah risk aversion yang salah satunya tercermin dari pertumbuhan kredit yang sebagian besar masih didominasi oleh kredit konsumsi, akan bermuara pada permasalahan tersendiri bagi peningkatan peran intermediasi bank, yaitu : pertama, tingginya $C A R$ mempengaruhi kemampuan bank dalam menyalurkan kredit; kedua, masalah NPL di tahun-tahun terakhir membuat bank lebih terfokus dalam upaya konsolidasi internal guna perbaikan kualitas aset daripad menyalurkan kredit; ketiga, risiko usaha yang masih tinggi menyebabkan bank terlalu berhati-hati dalam menyalurkan kredit; dan keempat, terjadinya informasi asimetrik dalam penyaluran kredit perbankan, karena bank tidak mempunyai informasi yang layak dalam penyaluran kredit perbankan.

Selanjutnya, permasalahan dari sisi dunia usaha juga tak kurang 
pengaruhnya terhadap belum optimalnya upaya peningkatan peran intermediasi perbankan di Indonesia. Pertumbuhan kredit yang cukup lambat dalam tahuntahun terakhir pasca krisis, tidak hanya dari sisi penawaran (kreditur) tetapi juga berasal dari sisi permintaan (debitur). Tingginya risiko serta ketidakpastian ekonomi menyebabkan kepercayaan para pelaku usaha terhadap kondisi ekonomi menjadi semakin menurun. Akibatnya, penyerapan kredit oleh kalangan dunia usaha juga menjadi relatif terbatas. Ketidaksiapan para pelaku di sektor riil ini misalnya, dapat dilihat dari besarnya undisbursed loan sepanjang tahun 2006 yang telah mencapai besaran fantatis yaitu Rp150 triliun.

Permasalahan dari sisi dunia usaha yang juga mengakibatkan terhambatnya penyaluran kredit perbankan ini, beberapa hal penting yang perlu dicatat adalah sebagai berikut: pertama, lingkungan usaha yang belum kondusif, misalnya: rendahnya kualitas dan kuantitas infrastruktur, rumitnya perijinan usaha, perpajakan, masih tingginya tingkat korupsi, belum stabilnya politik dan keamanan dan lainlain. Hambatan ini menyebabkan dunia usaha di Indonesia sulit berkembang dan pada gilirannya menyebabkan rendahnya tingkat pengembalian dunia usaha dalam prespektif perbankan. Kedua: risiko usaha yang masih tinggi, yang tercermin dari masih tingginya angka NPL terutama pada sektor-sektor primadona dalam penyaluran kredit; ketiga: rendahnya kapasitas produksi nasional. Hal ini erat kaitannya dengan masih banyak hambatan yang dihadapi dunia usaha. Hingga akhir tahun 2004, misalnya kapasitas produksi nasional masih berkisar 48\%. Dan keempat: rendahnya daya saing ekonomi Indonesia. Rendahnya daya saing perekonomian Indonesia membawa implikasi antara lain rendahnya tingkat investasi baik domestik maupun asing di Indonesia.

Usaha menggerakkan sektor riil melalui peningkatan peran intermediasi perbankan di Indonesia, tentu akan sulit terealisasi jika sejumlah permasahan yang ada belum terselesaikan. Belum terselesaikannya sejumlah permasalahan pada dunia usaha juga mengakibatkan terhambatnya penyaluran kredit perbankan kepada dunia usaha.

\section{PERKEMBANGAN PEMBIAYAAN TERHADAP SEKTOR UMKM}

$\begin{array}{ccr}\text { Krisis } & \text { yang } & \text { menerpa } \\ \text { perekonomian } & \text { Indonesia } & \text { pada }\end{array}$ pertengahan 1997 telah membawa dampak terhadap sendi-sendi kehidupan ekonomi masyarakat Indonesia. Tidak terkecuali bisnis korporasi dan sektor perbankan pun merasakan dampak langsungnya. Dalam kondisi yang demikian, ternyata justru usaha kecillah yang mampu menjadi katup pengaman perekonomian dengan kinerja yang cenderung relatif resisten terhadap goncangan ekonomi.

Dampak berat krisis moneter yang sangat dirasakan oleh unit bisnis beraset milyaran hingga trilyunan rupiah tersebut ternyata hampir tidak dirasakan sektor Usaha Mikro, Kecil dan Menengah (UMKM). Hal ini terutama antara lain disebabkan oleh tingginya kandungan lokal pada faktor produksi mereka, baik pada penggunaan bahan baku maupun permodalan. Selain itu, usaha mereka pada umumnya berbasis pada kebutuhan dasar masyarakat luas.

Namun demikian, bukan merupakan hal baru lagi jika upaya pengembangan sektor yang mempunyai peran sentral dalam perekonomian Indonesia ini banyak menemui kendala. Kendala yang dijumpai dalam upaya pengembangan UMKM tersebut tidak lepas dari persoalan dasar yaitu kelemahan internal usahanya sendiri 
(pelaku dan usahanya) dan juga kelemahan eksternal berupa hubungan dengan pelaku-pelaku lain yang terkait dalam usaha tersebut. Kelemahan internal UMKM yang dimaksud antara lain terkait dengan kapasitas manajemen dan wirausaha yang lemah, teknis produksi dan kurangnya infrastruktur. Infrastruktur yang dimaksud meliputi akses terhadap sumber modal, pasar, informasi, teknologi, sarana dan prasarana. Salah satu infrastuktur yang dibutuhkan adalah permodalan.

Permasalahan utama usaha mikro adalah permodalan. Secara rinci beberapa kesulitan dalam upaya pemberdayaan UMKM tersebut berturutturut adalah: kesulitan modal, pengadaan bahan baku, pemasaran dan kesulitan lainnya. Jenis kesulitan yang dihadapi usaha mikro tersebut, seperti tampak dalam Tabel 5 berikut:

Tabel 5. Jenis Kesulitan Usaha Mikro

\begin{tabular}{lcr}
\hline \multicolumn{1}{c}{ Jenis Kesulitan } & IKR & IK \\
\hline Kesulitan modal & $34.55 \%$ & $44.05 \%$ \\
Pengadaan bahan & $20.14 \%$ & $12.22 \%$ \\
baku & & \\
Pemasaran & $31.70 \%$ & $34.00 \%$ \\
Kesulitan lainnya & $13.60 \%$ & $9.73 \%$ \\
\hline
\end{tabular}

Ket; IKR : Industri Kecil Rumah Tangga; IK : Industri Kecil

Sumber: Ismawan (2003)

Berdasarkan hasil penelitian Bank Indonesia pada tahun 2005, sebagian besar UMKM (64,6\%) memerlukan kredit. Namun demikian, sumber pembiayaan usaha mikro dan kecil sebagian besar masih berasal dari modal pribadi dan modal keluarga. Modal sendiri merupakan pilihan utama pelaku usaha mikro (90.36\% untuk Industri Kecil Rumah Tangga dan $69.82 \%$ untuk Industri Kecil). Selengkapnya, hal ini dapat diamati pada Tabel 6 berikut ini:
Tabel 6. Darimana Modal Diperoleh Oleh Pelaku Usaha Mikro

\begin{tabular}{lrr}
\hline \multicolumn{1}{c}{ Uraian } & \multicolumn{1}{c}{ IKR } & \multicolumn{1}{c}{ IK } \\
\hline Modal Sendiri & $90.36 \%$ & $69.82 \%$ \\
Modal Pinjaman & $3.20 \%$ & $4.76 \%$ \\
Modal Sendiri dan & $6.44 \%$ & $25.42 \%$ \\
Pinjaman & & \\
Jumlah & $100 \%$ & $100 \%$ \\
\hline
\end{tabular}

Ket; IKR : Industri Kecil Rumah

Tangga; IK : Industri Kecil

Sumber: Ismawan (2003)

Sejalan dengan hal tersebut, survei BPS (1998) menyatakan bahwa keterbatasan akses modal sebagai kendala utama bagi usaha mikro $(40,5 \%)$ dan kecil $(36,6 \%)$ untuk berkembang.

Dalam menjawab persoalan mengapa permodalan menjadi kendala utama dalam upaya pengembangan UMKM, karena karakteristik UMKM Indonesia yang sebagian besar bergerak di sektor informallah, maka persoalan permodalan menjadi kendala dalam pengembangan ekses usaha. Sehingga, struktur permodalan yang bersumber dari kredit perbankan, baik berupa kredit modal kerja maupun kredit investasi, menjadi sangat penting bagi pengembangan UMKM di Indonesia. Hal ini mengingat bank adalah lembaga keuangan yang fungsi utamanya adalah menyalurkan kredit dalam rangka menjalankan fungsi intermediasinya.

Berkaitan dengan pentingnya kredit perbankan bagi pengembangan UMKM ini, interaksi antara perbankan dengan para pelaku ekonomi secara langsung melalui penyaluran kredit perbankan akan berpengaruh terhadap perkembangan berbagai aktivitas perekonomian. Dari sisi produksi perkembangan pembiayaan dalam bentuk kredit perbankan akan berpengaruh terhadap kemampuan produksi dunia usaha sehingga akan menentukan tingkat output riil dari berbagai sektor ekonomi. 
Dalam perkembangannnya, bagi pelaku UMKM ternyata bank bukan merupakan satu-satunya lembaga keuangan yang menjadi tumpuan UMKM dalam pembiayaan untuk usahanya. Beberapa lembaga keuangan lain yang juga menjadi pilihan bagi UMKM untuk membiayai usahanya, misalnya koperasi, atau bahkan lembaga keuangan non formal yang lain. Untuk kategori asal pinjaman dari lain-lain, bahkan prosentasenya lebih tinggi dari kategori yang lain. Tabel 7 menjelaskan hal ini secara mendetail.

Tabel 7. Asal Pinjaman Pelaku Usaha

\begin{tabular}{crr}
\multicolumn{3}{c}{ Mikro } \\
\hline Asal Pinjaman & \multicolumn{1}{c}{ IKR } & \multicolumn{1}{c}{ IK } \\
\hline Bank & $18.79 \%$ & $59.78 \%$ \\
Koperasi & $7.09 \%$ & $4.85 \%$ \\
Institusi & $8.25 \%$ & $7.63 \%$ \\
Lain & & \\
Lain-lain & $70.35 \%$ & $32.16 \%$ \\
\hline
\end{tabular}

Ket; IKR : Industri Kecil Rumah Tangga; IK : Industri Kecil

Sumber: Ismawan (2003)

Untuk mengatasi kesulitan permodalannya, hanya sebanyak $17,50 \%$ dari keseluruhan UMKM yang melakukan pinjaman ke bank, sedangkan sisanya sebanyak $82,50 \%$ ke lembaga non bank atau informal.

Mengenai gejala keengganan pelaku UMKM mengajukan kredit kepada bank, yang disebabkan beberapa alasan (misalnya karena prosedur yang sulit, tidak berminat dan tidak tahu prosedur, suku bunga tinggi, tidak punya agunan, atau proposal yang ditolak), Hal itulah yang terutama menjadi penyebab mengapa sektor UMKM di negaranegara berkembang pada umumnya masih menggantungkan diri pada pendanaan informal dengan resiko beban biaya modal yang sangat tinggi. UMKM enggan meminjam dana dari bank karena 'prosedur sulit', sementara di sisi lain pihak bank harus mengikuti prinsip kehati-hatian sebagai bagian dari manajemen resiko dalam penyaluran kredit.

Berhubungan dengan permasalahan permodalan bagi UMKM, permasalahan yang tengah dihadapi saat ini oleh UMKM adalah akses dalam mendapatkan fasilitas pembiayaan dari perbankan. Permasalahan tersebut pada dasarnya sangat terkait dengan profil dari debitur-debitur UMKM yang kebanyakan kurang atau bahkan tidak bankable (tidak memenuhi persyaratanpersyaratan teknis perbankan).

Tidak bankable-nya debitur UMKM menjadikan aspek kelayakan (feasibility) debitur UMKM terabaikan. Karena tidak dapat memenuhi persyaratan-persyaratan teknis perbankan, calon debitur UMKM kehilangan kesempatan untuk mendapatkan fasilitas kredit dari perbankan.

Dalam kaitan dengan ini terdapat juga keterangan tentang hal yang menjadi sebab kendala pembiayaan kepada UMKM. Salah satu temuan survey BI tahun 2005 mengenai profil UMKM di Indonesia adalah bahwa UMKM masih enggan mengambil kredit ke bank karena tidak adanya agunan (untuk debitor mikro) atau terlalu tingginya suku bunga bank (untuk debitor kecil dan menengah). Selain itu, survey BI tersebut juga mendukung realita mengapa jumlah UMKM di Indonesia hanya sekitar $12 \%$ saja yang mengambil kredit bank. Jawabannya adalah karena untuk kredit di atas Rp 50 juta, pada umumnya bank telah mensyaratkan dilengkapinya berbagai dokumen seperti ijin usaha dan legalitas perusahan (badan hukum), di mana kedua hal ini masih jarang dimiliki oleh sebagian besar UMKM.

Keadaan usaha mikro sebagai kegiatan ekonomi rakyat yang banyak dilakukan oleh masyarakat lapisan 
bawah, sehingga kelompok ini pada umumnya nyaris tidak tersentuh (undeserved) dan tidak dianggap memiliki potensi dana oleh lembaga keuangan formal, sehingga menyebabkan laju perkembangan ekonominya terhambat pada tingkat subsistensi saja. Kelompok masyarakat ini dinilai tidak layak bank (not bankable) karena tidak memiliki agunan, serta diasumsikan kemampuan mengembalikan pinjamannya rendah, kebiasaan menabung yang rendah, dan mahalnya biaya transaksi. Akibat asumsi tersebut, maka aksesibilitas dari pengusaha mikro terhadap sumber keuangan formal rendah, sehingga kebanyakan mereka mengandalkan modal apa adanya yang mereka miliki.

Sedangkan permasalahan permodalan lain dalam pembiayaan kepada UMKM adalah permasalahan yang dihadapi adalah oleh perbankan tetapi terkait erat dengan pelaku UMKM. Permasalahan tersebut misalnya; (i) asymmetric information, dan (ii) moral hazard. Permasalahan asymmetric information terjadi salah satunya karena pasar keuangan (perbankan dan non-perbankan) tidak mengetahui secara detail mengenai UMKM baik dari prospek dan risiko usaha, serta karakter nasabah. Sementara untuk permasalahan moral hazard terjadi karena adanya penggunaan kredit di luar peruntukan seharusnya tanpa sepengetahuan bank, dan biasanya kesalahan penggunaan kredit tersebut mengakibatkan terjadinya gagal bayar.

Pada akhirnya moral hazard akan mengakibatkan trauma bagi perbankan untuk menyalurkan kredit. Pada akhirnya, baik asymmetric information maupun moral hazard mengakibatkan terjadinya market failure, sehingga perlu ada langkah 'intervensi' untuk mengkoreksi kegagalan tersebut. 'Intervensi' itulah apa yang dimaksud dengan peran pemerintah pusat, daerah, Bank Indonesia, perbankan, departemen atau dinas teknis, dan institusi terkait lainnya. Hal ini sejalan pula dengan semangat pemberdayaan UMKM yang ramai didengungkan bahwa upaya memperkuat infrastruktur perekonomian Indonesia harus mencakup upaya menyeimbangkan peran sektor usaha besar dan sektor usaha kecil.

Kendala-kendala perbankan dalam menyalurkan kredit kepada sektor UMKM, antara lain: (1) Minimnya pengalaman dan kualitas pejabat bank dalam mengurus UMKM, Menganggap UMKM sebagai sektor yang complicated, high risk dan low profit, (3) Kerasnya prinsip kehati-hatian bank serta trauma krisis ekonomi, dan (4) Perubahan klien dari yang biasanya korporat ke UMKM, tidak mudah.

Upaya mengatasi permasalahan kesulitan permodalan oleh UMKM sebetulnya telah banyak digagas baik oleh lembaga-lembaga pemerhati usaha berskala kecil maupun oleh pemerintah sendiri. Tak kurang, pemerintah melalui Bank Indonesia telah mengeluarkan berbagai peraturan tentang dukungan pembiayaan terhadap UMKM. Misalnya saja serangkaian kebijakan yang disebut sebagai "Paket Kebijakan Perbankan Januari 2005" sebagai bentuk sinkronisasi atas arah kebijakan pemerintah dalam mengoptimalisasi fungsi intermediasi perbankan.

Peraturan tersebut dikenal dengan Pakjan 2005, yang terdiri dari delapan ketentuan, dalam bentuk Peraturan Bank Indonesia (PBI), baik bersifat baru, maupun penyempurnaan peraturan yang telah ada, dan mulai berlaku tanggal 20 Januari 2005. Salah satunya peraturan itu misalnya PBI No.7/3/PBI/2005 mengenai Batas Maksimum Pemberian Kredit (BMPK).

Sedangkan dukungan terhadap UMKM yang terbilang terbaru, adalah 
peresmian pelaksanaan program Kredit Usaha Rakyat (KUR) yang khusus ditujukan untuk memperkuat permodalan kelompok UMKM serta koperasi oleh Presiden Indonesia pada tanggal 5 November 2007.

Sayangnya, banyak bank besar yang sampai saat ini masih menganaktirikan UMKM dalam pengucuran kredit produksi. Gambaran realisasi pengucuran kredit perbankan dan kebijakan Bank Indonesia yang semakin berpihak pada sektor UMKM ternyata masih belum sejalan dengan kenyataan.

Fenomena ini menarik untuk dielaborasi lebih dalam, karena fakta di lapangan pada tataran pelaksanaan yang masih belum sejalan dengan tataran kebijaksanaan dapat menjadi indikasi adanya kesalahan atau sesuatu yang kurang dalam mekanisme pelaksanaannya. Kesenjangan atau gap yang ada ini masih membuka peluang untuk mendorong banyak studi yang akan mendukung pada penemuan format kebijakan-kebijakan lebih lanjut dalam rangka pelaksanaan API (Arsitektur Perbankan Indonesia).

Padahal, jika dicermati lebih jauh, sebetulnya pemberian kredit kepada sektor UKM sebenarnya tidak kalah menguntungkan dibanding pemberian kredit kepada korporasi. Keuntungan atas pemberian kredit kepada UMKM tersebut antara lain: (i) Tingkat kemacetan relatif kecil, (ii) Mendorong penyebaran risiko, karena nominalnya kecil dan nasabahnya banyak, dan (iii) Interest margin yang lebih besar.

Dari sisi yang lain, pembiayaan terhadap UMKM juga mempunyai keunggulan jika dilihat dari sifat usahanya yang self liquidating. Hal ini karena pada umumnya seluruh dana pembiayaan yang diperoleh dari lembaga keuangan digunakan untuk pembiayaan kegiatan usaha. Berbeda dengan usaha corporate, dimana biasanya pembiayaan yang didapatkan dari perbankan sebagian besar digunakan untuk pembiayaan investasi, atau melengkapi perusahaan dengan modal yang tetap.

Tepat pada wacana tentang self liquidating inilah, pentingnya membahas tentang pembiayaan terhadap UMKM. Sebab secara sejarah dan prinsip filosofi bank, semua jenis pembiayaan (pada sektor usaha yang besar maupun kecil), bisa dilakukan oleh bank, selama usaha tersebut bersifat self liquidating. Teori pemberian pinjaman untuk dagang, the commercial loan theory, bank-bank hanya boleh memberikan pinjaman dengan surat dagang jangka pendek yang dapat dicairkan dengan sendirinya (selfliquidating), karena sifat sesungguhnya dari pinjaman itu ialah menghasilkan uang yang diperlukan untuk membayarnya kembali.

Pembahasan tentang UMKM, termasuk dalam wilayah bahasan tentang usaha, khususnya usaha kecil. Pengertian dan karakteristik usaha kecil sendiri di Indonesia masih sangat beragam. Departemen Perindustrian dan Bank Indonesia (1990) mendefinisikan usaha kecil berdasarkan nilai asetnya, yaitu suatu usaha yang asetnya (tidak termasuk tanah dan bangunan) bernilai kurang dari Rp. 600 Juta. Sedangkan Departemen Perdagangan mendefinisikan usaha kecil sebagai usaha yang modal kerjanya kurang dari Rp. 25 Juta.

Menurut Badan Pusat Statistik (BPS), industri kecil adalah usaha industri yang melibatkan tenaga kerja antara 5 sampai dengan 19 orang. Sedangkan industri rumah tangga adalah usaha industri yang memperkerjakan kurang dari 5 orang.

Terdapat salah satu definisi yang dapat dipakai untuk menilai kategori usaha dengan versi yang lebih baru, misalnya definisi berdasarkan Surat 
Edaran Bank Indonesia kepada Semua Bank Umum di Indonesia No.3/9/BKr, tertanggal 17 Mei 2001. Menurut Surat Edaran ini, Usaha Kecil adalah usaha yang memenuhi beberapa kriteria, yaitu: (a) Memiliki kekayaan bersih paling banyak Rp. 200.000.000,00 (dua ratus juta rupiah) tidak termasuk tanah dan bangunan tempat usaha; atau (b) Memiliki hasil penjualan tahunan paling banyak Rp. 1.000.000,00 (satu miliar rupiah); (c) Milik Warga Negara Indonesia; (d) Berdiri sendiri, bukan merupakan anak perusahaan atau cabang perusahaan yang dimiliki, dikuasai, atau berafiliasi baik langsung, maupun tidak langsung dengan usaha menengah atau usaha besar; dan (e) Berbentuk usaha perorangan, badan usaha yang tidak berbadan hukum, atau badan usaha yang berbadan hukum, termasuk koperasi.

Jika pengertian usaha kecil masih sangat beragam, maka menyimpulkan pengertian UMKM juga merupakan hal yang sulit juga karena beragamnya definisi UMKM yang merupakan bagian dari pembahasan mengenai usaha kecil. Salah satu acuan yang bisa digunakan untuk menjelaskan UMKM adalah definisi UMKM menurut temuan survey BI tahun 2005 mengenai profil UMKM di Indonesia. Menurut survey ini, secara umum Profil UMKM di Indonesia dapat dirumuskan seperti dalam Tabel 7 berikut ini:

Meskipun terdapat beragam versi mengenai definisi UMKM, terdapat fokus definisi UMKM yang dipakai kalangan perbankan untuk tujuan pencatatan statistik dan keseragaman data. Fokus definisi UMKM Bagi bank tersebut didasarkan pada: (i) Omset Penjualan Setahun, (ii) Kemampuan Membayar Kembali Kredit Bank, (iii) Kemampuan Menghasilkan Laba Usaha, (iv) Kekayaan Bersih, (v) Jumlah Kredit yang diberikan, dan (vi) Jumlah Tenaga Kerja yang Dipakai.
Beragamnya definisi tersebut, merupakan hal yang menarik, karena beragamnya definisi UMKM akan berderivasi terhadap penetapan kebijakan yang tidak fokus, yang akan cenderung disesuaikan dengan kepentingan pembuat kebijakan itu sendiri.

Di luar pembahasan mengenai beragamnya definisi UMKM, fakta tentang keberadaan sifat dan fenomena UMKM sendiri merupakan hal menarik untuk dielaborasi lebih dalam. Hal ini berkaitan dengan fenomena ekonomi UMKM terkait dengan sifat kelokalannya dan juga sifat kekhasan/keunikannya.

Sifat kelokalan UMKM, terutama dicerminkan oleh tingginya kandungan lokal pada faktor produksi mereka, baik pada penggunaan bahan baku maupun permodalan. Selain itu, usaha mereka pada umumnya berbasis pada kebutuhan dasar masyarakat luas. Karena berbasis pada kebutuhan masyarakat luas, maka umumnya membuat banyak UMKM juga intensif dalam menggunakan sumberdaya alam lokal. Keadaan ini membuat UMKM cenderung menyerap banyak tenaga kerja. Karenanya, wajar jika pertumbuhan UMKM akan menimbulkan dampak positif terhadap peningkatan jumlah tenaga kerja, pengurangan jumlah kemiskinan, bahkan pemerataan dalam distribusi pendapatan.

Sedangkan sifat kekhasan/keunikan UMKM dicerminkan oleh sifat UMKM yang lentur atau fleksibel, dan daya survive-nya yang tinggi. Kelenturan atau sifat fleksibel UMKM, terkait dengan karakteristik umum UMKM yang kebanyakan bersifat informal. Sebagaimana dipahami, secara umum, karena sifat informalnya, mereka tidak terpaku dengan aturan formal yang kebanyakan bersifat baku dan mengikat. 
Tabel 8. Survei Profil UMKM di Indonesia

\begin{tabular}{ll}
\hline No. & \multicolumn{1}{c}{ Karakteristik umum } \\
\hline 1 & Rendahnya kesadaran memiliki ijin usaha \\
2 & Enggan mengambil kredit bank (terkait soal agunan untuk nasabah mikro; \\
& Dan terkait soal suku bunga tinggi untuk nasabah usaha kecil dan menengah) \\
3 & Masih mengandalkan pada sumber dana non bank (modal sendiri) \\
4 & Harga bahan baku yang tidak stabil \\
5 & Kualitas yang tidak standar (kontrol kualitas dilakukan secara manual) \\
6 & Rendahnya ketrampilan pengusaha umkm \\
7 & Pada umumnya belum berbadan hukum
\end{tabular}

(Sumber: Bank Indonesia, 2005 dalam Retnadi, 2007:8, diolah)

Di sisi lain, kelenturan ini membawa dampak dan keuntungan sendiri, dimana UMKM menjadi mudah menyesuaikan dengan keadaan pasar. Itulah salah satu alasan yang menjelaskan mengapa dampak berat krisis moneter yang pernah menerpa ekonomi Indonesia, yang sangat dirasakan oleh unit bisnis besar beraset milyaran hingga trilyunan rupiah, ternyata hampir tidak dirasakan sektor UMKM.

Dari sisi kebijakan, sifat kelokalan dan keunikan/kekhasan UMKM ini jelas menguntungkan karena tidak saja memberikan penghasilan bagi sebagian besar angkatan kerja Indonesia, namun juga merupakan salah satu ujung tombak dalam upaya pengentasan kemiskinan. Lebih jauh, peran penting UMKM dalam memberikan tambahan pendapatan dapat berfungsi sebagai strategi mempertahankan hidup (survival strategy) di tengah hantaman krisis ekonomi. Sehingga, tidaklah berlebihan jika UMKM memiliki ketahanan yang lebih baik dibandingkan dengan usaha besar karena lebih efisien.

Pembahasan mengenai UMKM tidak bisa dilepaskan dari analisis terhadap kekhasan/keunikan fenomena ekonomi dan kelokalan sifatnya. Karenanya, analisis terhadap persoalan yang menyangkut UMKM akan bersifat multidimensional. Karena sifatnya multidimensional, maka tinjauan terhadapnya akan bersifat interdisiplin. Pentingnya bahasan yang bersifat intedisiplin, misalnya, diperlukan untuk membahas tentang aspek pembiayaan terhadap UMKM. Hal ini penting, karena jika hanya aspek ekonomi dan bisnis saja -aspek yang terkait langsung dengan pembiayaan atau kredit- yang digunakan untuk menganalisis masalah tersebut, maka tidak akan didapat analisis yang akurat, lengkap dan mendalam.

Pembiayaan terhadap usaha berskala kecil, tentu suatu hal yang sulit dilakukan oleh bank. Hal ini karena bank adalah lembaga bisnis, yang sudah pasti tujuan dan dasar utama kegiatannya adalah profit. Bagi bank, pembiayaan terhadap UMKM dinilai sebagai suatu kegiatan yang tidak berorientasi profit. Salah satu alasannya adalah pihak bank harus mengikuti prinsip kehati-hatian sebagai bagian dari manajemen resiko dalam penyaluran kredit serta mahalnya biaya transaksi yang harus ditanggung oleh bank.

Umumnya kredit UMKM nominalnya kecil dan jumlah nasabahnya banyak. Pada gilirannya, hal inilah yang menyebabkan tingginya biaya transaksi yang harus ditanggung oleh bank. Pengalaman menunjukkan bahwa biaya transaksi yang dikeluarkan bank untuk pekerjaan administratif 
relatif sama untuk jumlah nilai kredit yang berbeda. Sehingga bagi bank akan lebih menguntungkan memberikan kredit dalam jumlah besar dibanding jumlah kecil-kecil.

Sedangkan kondisi yang berkaitan dengan tingginya risiko yang dihadapi bank dalam pemberian kredit kepada usaha kecil, ternyata hal ini adalah karena usaha kecil umumnya mempunyai keuntungan dan cash flow yang berfluktuasi, serta menggunakan pinjaman yang lebih besar dibanding dengan kekayaan bersih. Ditambah lagi dengan sulitnya mendapatkan informasi yang akurat mengenai keadaan keuangannya.

Disinilah pentingnya pembahasan 'lain', dimana analisis terhadap kredit UMKM tidak hanya didasarkan pada tingginya risiko karena prinsip kehatihatian dalam penyaluran kredit dan mahalnya biaya transaksi saja. Di samping dua aspek tersebut, kelengkapan analisis semestinya juga mempertimbangkan aspek lain, misalnya tinjauan tentang 'aturan main' dalam kehidupan masyarakat. Bagaimanapun, aturan main juga sangat menentukan berlangsungnya proses intermediasi bank terhadap UMKM. Sebagai contoh, misalnya tentang penerapan kriteria $5 \mathrm{C}$ pada saat pertama kali mengajukan kredit ke bank, tapi jika berulang (kredit berikutnya), aturan $5 \mathrm{C}$ tidak terlalu ketat diterapkan, karena bank telah memperoleh pengalaman tentang kelayakan dari pemohon atau calon debitur.

Aturan main adalah inti dari kajian kelembagaan. Sedangkan kelembagaan sendiri merupakan suatu hal penting dalam kehidupan masyarakat, karena kelembagaan adalah seperangkat aturan yang dianut oleh sekelompok masyarakat yang dijadikan sebagai pegangan dalam mengadakan bargaining dengan individu maupun dengan kelompok lain. Secara umum kelembagaan merupakan serangkaian aturan perilaku yang biasanya terlihat pada individu di sebuah komunitas. Kelembagaan merefleksikan sistem nilai dan norma dalam masyarakat. Secara umum, aturan main dalam kelembagaan memiliki tiga komponen, yaitu: (i) aturan formal (eksternal), (ii) aturan informal (internal), dan (iii) mekanisme penegakan (enforcement mechanism). Contoh aturan formal antara lain konstitusi, atau regulasi pemerintah, sedangkan aturan informal meliputi pengalaman, nilai-nilai tradisional, agama, dan lain-lain. Sedangkan penegakan, mengisyaratkan bahwa semua aspek kelembagaan tidak akan efektif jika tanpa dampingan mekanisme penegakan.

Aturan main dalam kasus proses intermediasi perbankan terhadap UMKM dapat dijelaskan melalui tiga komponen tersebut di atas. Jika pertimbangan kredit kepada UMKM hanya didasarkan pada tinjauan terhadap tingginya risiko karena prinsip kehati-hatian bank dan mahalnya biaya transaksi saja, maka peningkatan peran intermediasi yang diharapkan tentu tidak akan berjalan efektif. Namun dengan mempertimbangkan prinsip kelembagaan (aturan main dan juga penegakan), hal yang secara perhitungan bisnis tidak mungkin, bisa saja terjadi. Karena dalam kajian ekonomi kelembagaan prilaku individu atau kelompok tidak harus dipahami sebagai tindakan yang diasumsikan 'rasional' secara ekonomi semata, namun juga mempertimbangkan kemungkinan munculnya prilaku di luar pertimbangan rasionalitas secara ekonomi.

\section{PENUTUP}

$\begin{array}{crr}\text { Dalam melaksanakan } & \text { proses } \\ \text { intermediasinya, } & \text { seharusnya } & \text { Bank }\end{array}$ 
berhadapan secara langsung dengan calon nasabah (UMKM). Namun, pada kenyataannya terdapat ketidaksesuaian antara kebutuhan permodalan/pendanaan UMKM dalam jumlah yang kecil dengan fleksibilitas dan mekanisme yang sederhana. Di lain pihak, bank pada umumnya memberikan kredit yang jumlahnya jauh lebih besar dari kebutuhan nasabah UMKM. Sementara untuk pinjaman dengan jumlah yang kecil untuk setiap nasabah akan berdampak pada biaya per unit yang mahal. Atas realitas ini, tampaknya keberadaan semacam lembaga penjamin yang menjadi penghubung antara UMKM dengan skala sangat kecil dengan perbankan, bisa menjadi pilihan untuk menjembatani keduanya. Artinya, pihak bank memberikan pinjaman kepada satu lembaga penjamin tersebut dengan jumlah yang besar, dan selanjutnya, lembaga penjamin tersebutlah yang memberikan pinjaman dalam jumlah yang kecil, sesuai dengan kebutuhan pelaku UMKM.

Dengan perlibatan lembaga penjamin ini, bisa jadi akan menambah biaya kredit itu sendiri. Tetapi, biaya tambahan yang timbul ini akan tertutupi atau bahkan lebih rendah, jika dibandingkan dengan manfaat dari besarnya kredit yang dapat tersalurkan. Sehingga, dengan mempertimbangkan kondisi yang sedemikian rupa, pengembangan UMKM dalam bentuk pemberian kredit yang merupakan cerminan berjalannya proses intermediasi bank terhadap UMKM yang diharapkan dapat terlaksana sesuai harapan.

Perlibatan lembaga penjamin
dalam rangka peningkatan peran
intermediasi perbankan terhadap UMKM
kiranya adalah keniscayaan yang dapat
dilakukan dalam rangka menjembatani
ketidaksesuaian antara pihak bank

sebagai kreditur dan pelaku UMKM sebagai debitur.

Namun demikian, terhadap keberadaan lembaga ini kiranya masih perlu dilakukan uji kelayakan, penentuan desain terhadap bentuk, prasyarat, prosedur ataupun mekanisme pelaksanaannya.

\section{DAFTAR PUSTAKA}

Adiningsih, Sri (2004) Regulasi Dalam Revitalisasi Usaha Kecil dan Menengah $d l \quad$ Indonesia, http://lfip.org/english/pdf/baliseminar, didownload pada tanggal 14 April 2007

Arief, Sritua (1993), Metode Penelitian Ekonomi, UI-Press, Jakarta

Bank Indonesia (1995), Pedoman Penyusunan Laporan Bulanan Bank Perkreditan Rakyat, Bank Indonesia, Jakarta.

Bank Indonesia Malang (2003) Informasi Kinerja BPR di Wilayah Kodya dan Kabupaten Malang, makalah disampaikan pada pertemuan rutin Bank Indonesia Malang dengan BPR-BPR sewilayah Kantor Bank Indonesia Malang di Hotel Graha Cakra Tanggal 21 Oktober 2003, Malang, tidak dipublikasikan.

Bank Indonesia (2006), Kajian Pembiayaan dalam Rangka Pengembangan Klaster, Laporan Penelitian oleh Tim Penelitian dan Pengembangan Biro Kredit Bank Indonesia (BKBI), Jakarta 
Bonis, R. De and Stacchini, M. (2005), On The Determinants of Banking Intermediation In Industrialized Countries, www.ceistorvergata.it, diakses pada tanggal 13 Desember 2007

Dahlan, Siamat (1995), Manajemen Lembaga Keuangan, Cetakan Pertama, Penerbit Intermedia, Jakarta

Firdaus, Rachmat dan Maya Ariyanti, (2003) Manajemen Perkreditan Bank Umum, Teori, Masalah, Kebijakan dan Aplikasinya, Lengkap dengan Analisis Kredit, Cetakan Pertama, Penerbit Alfabeta, Bandung.

Gandapradja, Permadi, (2004) Dasar dan Prinsip Pengawasan Bank. Cetakan Pertama. PT Gramedia Pustaka Utama, Jakarta.

Harris, M (2002), Pemberdayaan Usaha Kecil Menengah Dan Koperasi : Karakeristik, Kendala dan Alternatif Solusinya, Makalah disampaikan pada Lokakarya Nasional "Pengembangan Ekonomi Daerah Melalui Sinergitas Pengembangan Kawasan", diselenggarakan Oleh Direktorat Pengembangan Kawasan Khusus dan Tertinggal, BAPPENAS, Tanggal 4 November 2002, di Jakarta

Harmanta Dan Mahyus Ekananda (2005), Disintermediasi Fungsi Perbankan Di Indonesia Pasca Krisis 1997 : Faktor Permintaan Atau Penawaran Kredit, Sebuah Pendekatan Dengan Model Disequilibrium, Buletin Ekonomi Moneter Dan Perbankan, Juni 2005, h. 51-78
Hayashi, M. (2002), The Role of Subcontracting in SME development in Indonesia: Microlevel Evidence From the Metal Working and Machinery Industry, Journal of Asian Economics, v.13, pp. 1-26

Hill, H. (2001), Small and Medium Enterprise in Indonesia: Old Policy Challenges for the New Administration, Asian Survey, v.41, pp. 248-270

Hill, H dan Brennan (2000), A Methodology for Identifying The Drivers of Industrial Clusters: The Foundation Of Regional Competitive Advantage, Economic Development Quarterly 14 (2000), pp. 65-96.

Jurnal KUKM: Koperasi, Usaha Kecil dan Menengah (2007), Suplemen Khusus Media Indonesia, Edisi November

Media Indonesia Online (2007), Mendorong Implementasi Fungsi Intermediasi,

http://www.mediaindonesia.com/n ewsprint, diakses pada tanggal 29 Juni 2007

Meydianawathi, Luh Gede (2007), Analisis Perilaku Penawaran Kredit Perbankan Kepada Sektor UMKM di Indonesia (20022006), Buletin Studi Ekonomi Volume 12 Nomor 2

$\begin{array}{ccr}\text { Minha, Amruzi } & (2007), & \text { Peran } \\ \text { Perbankan } & \text { Tak } & \text { Kunjung } \\ \text { Menyentuh } & S i & \text { Mikro, }\end{array}$


http://www.kinerjabank.com, didown load pada tanggal $10 \mathrm{Mei}$

Purwanto, Deniey Adi (2005), Menggerakkan Dunia Usaha Melalui Pemulihan Intermediasi Perbankan: Tantangan dan Solusi, www.indef.or.id, diakses pada tanggal 25 Desember 2007

Retnadi (2007), Peran Kredit UMKM, Peluang Dan Tantangan, Economic Review No. 207, Maret 2007

Rudjito (2003), Sinergi Kebijakan Dalam Mendorong Pertumbuhan Usaha Mikro Kecil Dan Menengah, Materi Lokakarya "Mendorong Pertumbuhan Usaha Kecil Dan Menengah Yang Sehat Dan Berdaya Saing” diselenggarakan Oleh Asosiasi Pengusaha Indonesia (APINDO) Jakarta, 12 Desember 2003, tidak dipublikasikan

Thalo, Nawa (2005), Mengapa Intermediasi Perbankan Berjalan Lambat?, Policy Assessment, Juni, www.theindonesianinstitute.com, diakses pada tanggal 19 Desember 2007

Warjiyo, Perry (2004), Pembiayaan Pembangunan Sektor UMKM: Perkembangan Dan Strategi Ke Depan, Infokop Nomor 25 Tahun $\mathrm{XX}$. 